\title{
MINERALOGY AND RADIOACTIVITY OF EL-ROSIS SHEAR ZONE, SOUTHERN SINAI, EGYPT.
}

\author{
Azzaz S. A., El-Aassy* I. E., Sherif* H. M. and Bishr*, A. H.A.
}

Department of Geology, Faculty of Science, Zagazig University, Zagazig, Egypt *Nuclear Materials Authority, P.O.Box 530, Maadi, Cairo, Egypt

(Received: 9 July 2007)

\begin{abstract}
El-Rosis area is mainly covered by syeno- and alkali feldspar granites intruded into the granodiorites with sharp contacts. The alkali feldspar granite is dissected by WNW-ESE shear zone along which alteration products such as hematitization and kaolinitization are observed. The detailed radiometric survey along the shear zone revealed the presence of numerous radiometric anomalies. The X-ray diffraction (XRD) and Environmental Scanning Electron Microscope (ESEM) studies on the anomalous samples revealed the presence of cliffordite mineral (UTe309) and U-bearing zircon.

The distribution of uranium, thorium and potassium along the shear zone is also studied in detail and a radiometric contour map of each element is constructed to illustrate its distribution. The obtained contour maps show that the distribution of these elements is largely controlled by the fracture system developed along the shear zone and the presence of the alteration products containing iron and copper mineralizations. The alteration products and the minerals identified may suggest hydrothermal activity in the shear zone.
\end{abstract}

\section{Introduction}

El-Rosis area is located in the southeastern part of Saint Katherina city and south Wadi Isbaiya (Fig. 1) and can be reached via Wadi El-Sheikh about $120 \mathrm{Km}$ to the east of the Gulf of Suez. The area is covered by granodiorite, syenogranite and alkali feldspar granite. Although the geology of the areas surrounding Wadi ElRosis is studied by many authors (Barron, 1907; El-Shazly et al. 1974; Eyal 1975; El-Ghawaby 1984; El-Shishtawy, 1984; Ibrahim, 1991 and Niazy et al. 1995), the present study is considered as the first detailed mineralogical and radiometrical studies carried out at EI-Rosis shear zone. Ibrahim (op.cit) concluded that the uranium and thorium mineralizations of Wadi EI-Regita and Um Alawi areas were formed along two episodes. The first, thorium minerals with secondary copper minerals were formed by hydrothermal solution along fault trend WNW and the second, uranium-bearing minerals by hydrothermal solution and pneumatolytic gasses along younger fault trend N-S. El-Ghawaby et al. (2000) concluded that the hydrothermal mineralization of Saint Katherina area has been ejected during the late stage of the intrusion of the granitic magma along inherited tensional Precambrian fabrics. The spatial distribution of the copper mineralized sites in Saint Katherina area shows a close relation with alteration, faults and dykes. The 
aim of this study is to investigate, in detail, the mineralogy and radioactivity of ElRosis shear zone area.

\section{GEOLOGIC OUTLINES}

The rock units present in El-Rosis area are shown on the geological map (Fig. 1). They are older granites (granodiorite) and younger granites (syenogranite and alkali feldspar granite).

The granodiorites exposed at the southeastern part of the mapped area, form moderate to high relief mountains, coarse to medium-grained and pinkish grey to light grey in colour with a marked inequigranular texture: The contacts of granodiorite with the neighboring rocks are always sharp. The granodiorites are highly jointed with dominated NNW-SSE, ENE-WSW and N-S joint sets.

Younger granites are the most dominant rocks exposed in El-Rosis area. They are classified mainly as syenogranite and alkali feldspar granite. Syenogranites are medium-to coarse-grained with pink to red in colour. It is highly jointed with NE-SW and NW-SE trends and show moderate to high degree of weathering prossess. Alkali feldspar granites are the youngest granite phase in the studied area, named as Iqna granites by Shimron, (1980) and Bentor, (1985) or as Girgar granites by Eyal and Hezkiyahu, (1980). The rocks are coarse- to medium-grained, commonly massive and hard, showing sharp contacts with syenogranites.

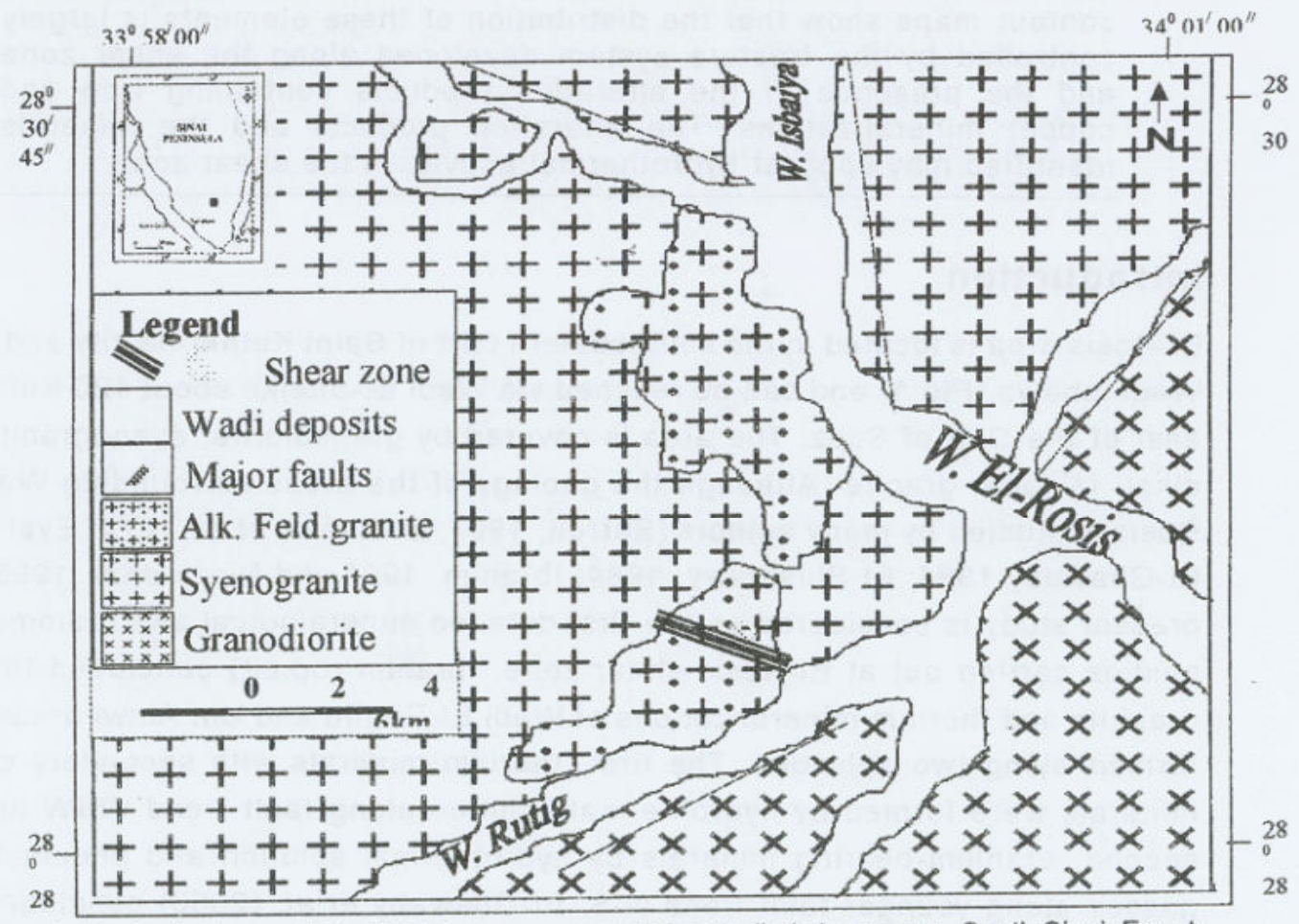

Fig. 1. Geological map of Wadi El-Rosis area around the studied shear zone, South Sinai, Egypt. 
The alkali feldspar granites are usually red in colour, and homogeneous in composition and in grain sizes. It possesses two sets of joints trending in NW-SE and NE-SW directions. Along the alkali feldspar granite of El-Rosis area, the shear zone is observed (Fig. 2). The trend of that shear zone is N 60-70 W, and has length of about $70 \mathrm{~m}$. and width ranged between 2.5 to $4.5 \mathrm{~m}$. The shear zone area is characterized by copper staining on wallrock in some parts. Along the shear zone there are moderate to weakly altered spots with development of argillic and hematitization processes and the formation of clay minerals such as Kaolinite. Some parts of the shear zone are characterized by yellow secondary uranium mineralization as cavity filling with high radioactivity.

\section{MINERALOGY}

\section{Uranium mineralization of El-Rosis shear zone}

The uranium and uraniferous minerals of El-Rosis shear zone are separated and identified on the basis of radioactive and physical properties beside to the XRD and ESEM techniques.
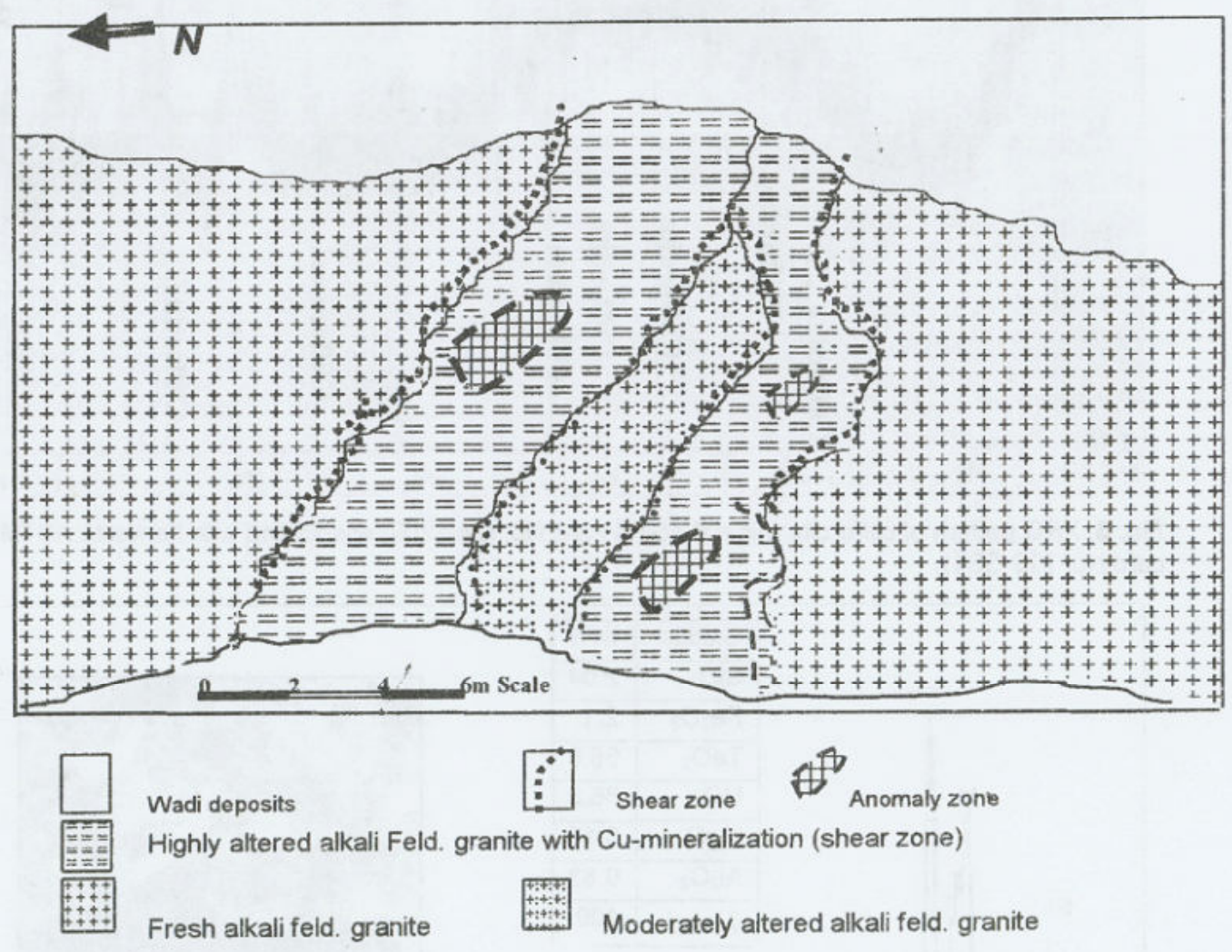

Fig. 2. Sketch map of El-Rosis shear zone showing wallrock alterations.

\section{Cliffordite $\left(\mathrm{UTe}_{3} \mathrm{O}_{9}\right)$}

Cliffordite is a type of uranyle tellurates minerals which have been described since Frondel (1958). XRD was used to identify cliffordite mineral (Fig. 3) which 
shows the associated iron oxide minerals pattern appear with cliffordite in the same XRD pattern.

It is found in El-Rosis shear zone associated with Cu-minerals, and hematite (plate 1.A). From field observations, the cliffordite mineral is collected from samples of high radioactive spots. After separation, the cliffordite mineral appears by its yellow colour and adamantine luster.

According to Gaines, (1969) cliffordite occurs as rare incrustations along fractures in the oxidized zone of hydrothermal Au-Ag telluride deposits, found with major components $\mathrm{UO}_{2}(35.31 \mathrm{wt} \%)$ and $\mathrm{TeO}_{2}(62.6 \mathrm{wt} \%)$.

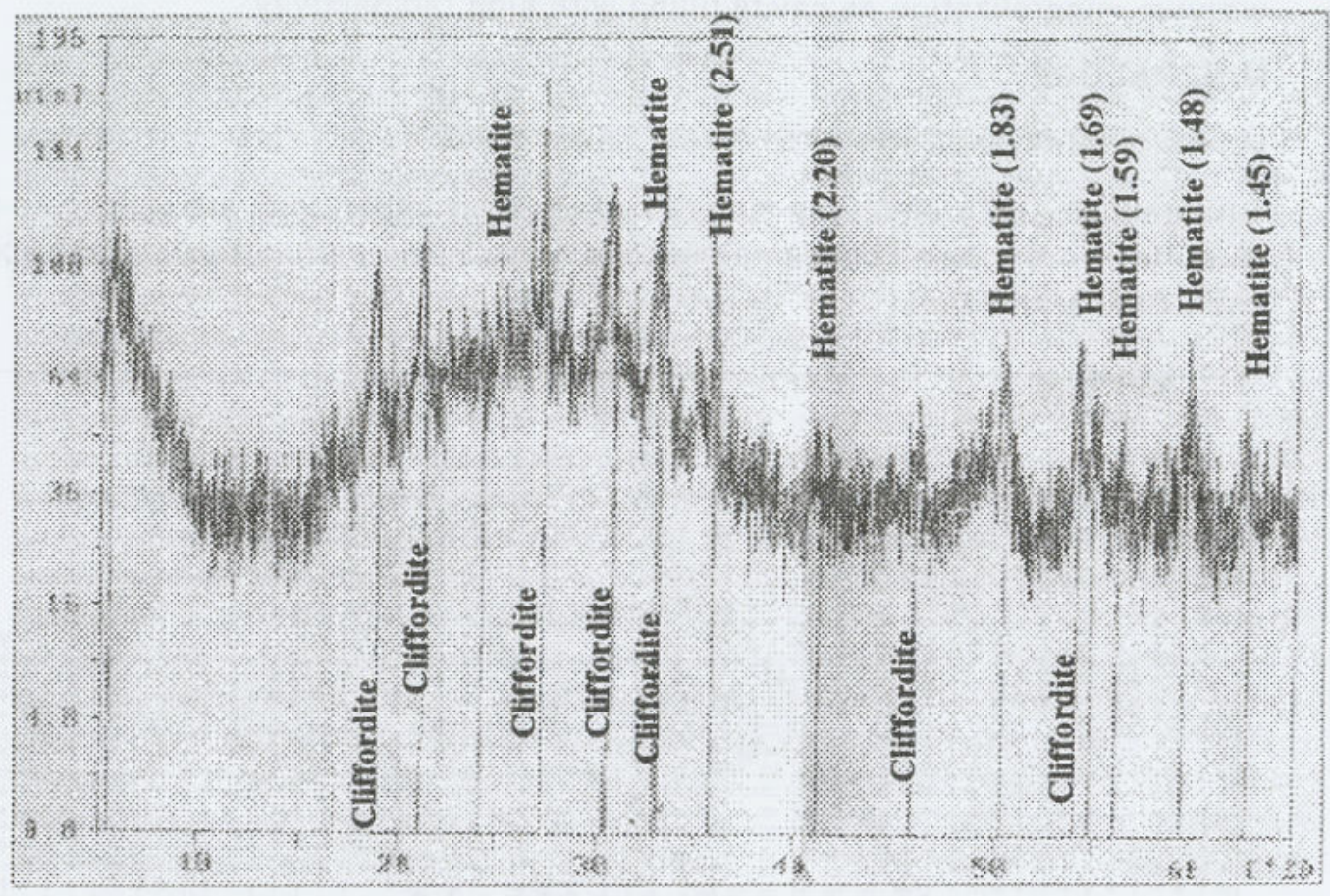

Fig. 3. XRD pattern of cliffordite mineral ASTM card No. (24-1209) associated with hematite ASTM card No. (13-534)

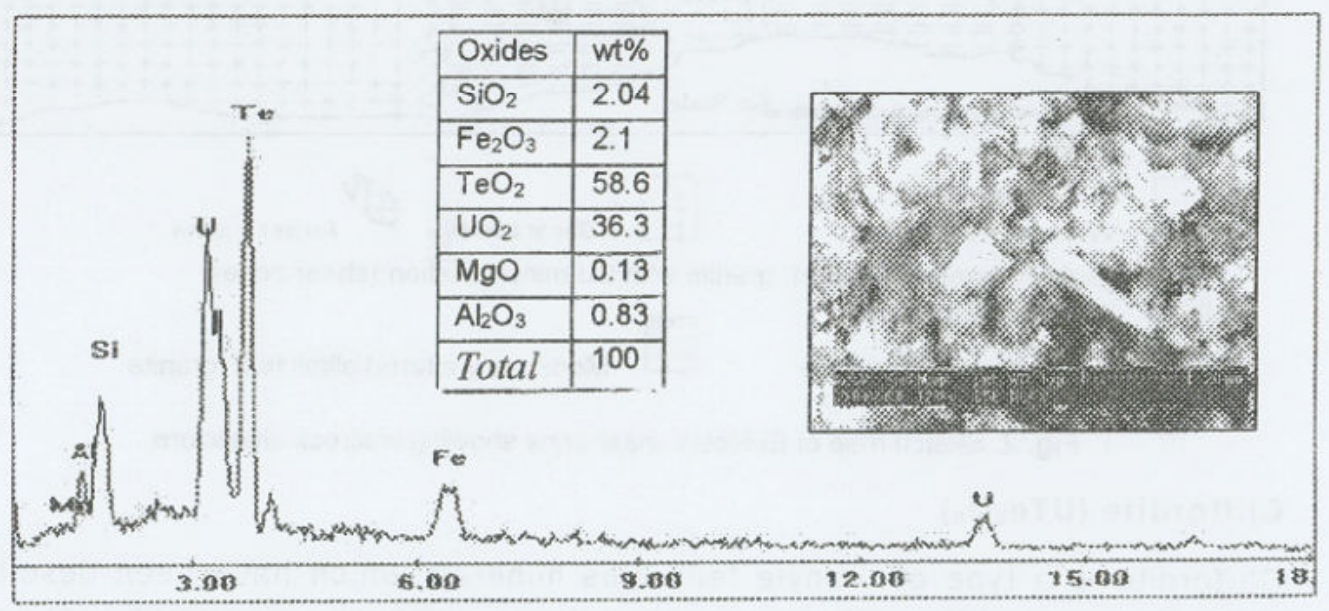

Fig. 4. Backscattered electron image and the chart of the analysed grain of cliffordite mineral. 
The analyses of some cliffordite grains by the ESEM technique (Fig. 4) shows that their main composition are UO2 (36.3 wt \%) and TeO2 (58.6 wt \%), also contains significant amounts of $\mathrm{SiO} 2(2.04 \mathrm{wt} \%)$.

\section{Zircon $\mathrm{ZrSiO}_{4}$}

It is a common accessory mineral belonging to the group of silicates in many igneous rock types and is also chemically and physically resistant to erosion. Zircon crystals appear in most separated samples of the studied granite rocks around the shear zone.

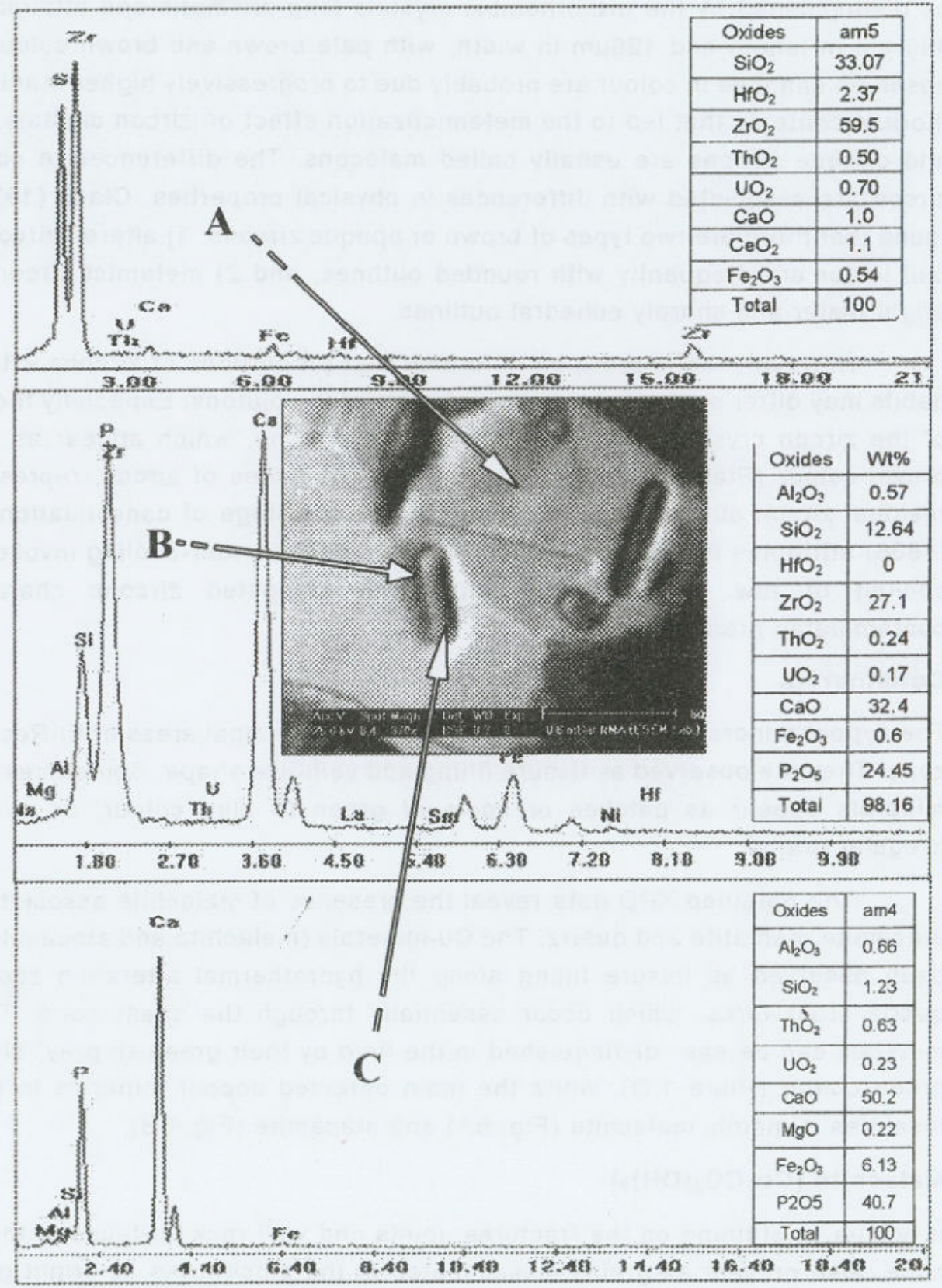

Fig. 5. BSE image of zircon contain apatite and the charts of the analyses of apatite inclusion on the surface of zircon crystals. $A=$ Zircon $B=$ in-between zircon and apatite $C=$ Apatite. 
They attain colourless, brown and reddish brown colour. Fresh euhedral zircon crystals show adamantine luster (Plate 1.B). While, metamict zircon have resinous luster (Plate 1.C).

Surface morphologies of zircons have examined using ESEM show some inclusions of apatite minerals are observed on the surfaces of zircon crystals and appear as simultanous over growths (Fig. 5), which suggests that zircon postdates apatite in these rocks.

Zircon crystals from the alkali-feldspar granite of El-Rosis shear zone can be distinguished by the orthorhombic crystals long-prismatic and attaining 200$450 \mu \mathrm{m}$ in length and $120 \mu \mathrm{m}$ in width, with pale brown and brown colours. The observed changes in colour are probably due to progressively higher uranium and thorium contents that led to the metamictization effect on zircon crystals. Brown and opaque zircons are usually called malacons. The differences in colour of zircon are associated with differences in physical properties. Claus (1936) has found that there are two types of brown or opaque zircons: 1) altered zircons with dull luster and frequently with rounded outlines, and 2) metamict zircons, with bright luster and sharply euhedral outlines.

However, the impression is formed that proportions of zircons with these habits may differ somewhat in different parts of the plutons. Especially the colour of the zircon crystals present within the shear zone, which appear as reddish brown colour (Plate 1.C). Long prismatic fine needles of zircon, represent the residual zircon substance crystallizing in the last stage of consolidation. Claus (1936) attributes this habit of zircons to pronounced under-cooling invokes rapid cooling or low. Wyatt (1954) finds that elongated zircons characterize contaminated granites

\section{Cu-minerals}

The copper mineralizations were recorded in two principal areas of El-Rosis shear zone. They are observed as fissure filling and vein-like shape. Sometimes the $\mathrm{Cu}-$ minerals appear as patches or spots of green to blue colour, or as coarse irregular grains.

The obtained XRD data reveal the presence of malachite associated with atacamite, hematite and quartz. The $\mathrm{Cu}$-minerals (malachite and atacamite) have been observed as fissure filling along the hydrothermal alteration zones and quartz stockworks, which occur essentially through the shear zone. The $\mathrm{Cu}-$ minerals can be easy distinguished in the field by their greenish grey, blue, and green colour (Plate 1.D), while the main detected copper minerals in the two localities is mainly malachite (Fig. 6A) and atacamite (Fig. 6B).

\section{Malachite $\left(\mathrm{Cu}_{2} \mathrm{CO}_{3}(\mathrm{OH})_{2}\right)$}

It occurs as staining on the fractures, joints and wall rock surfaces of the shear zone, also present as grains disseminated in the stockworks as bright green to blue colour and dull luster. 


\section{Atacamite $\left(\mathrm{Cu}_{2} \mathrm{Cl}(\mathrm{OH})_{3}\right)$}

It occurs as minute aggregates (cavity filling). The colour of atacamite is green, transparent to translucent and shows radiated acicular fibers habit.

\section{Radioactivity}

In order to get an idea about the distribution of the radio-elements along El-Rosis shear zone, a multi-channel instrument model GS-256 (designed by Geofyzika Brno-Czech Republic) is used to measure Tc (total radioactivity in Ur), $\mathrm{K} \%$, $\mathrm{eU}(\mathrm{ppm})$ and $\mathrm{eTh}(\mathrm{ppm})$ on rocks exposures. Grid patterns using compass and tape are constructed. The intervals between each successive profile are usually 5 meter.

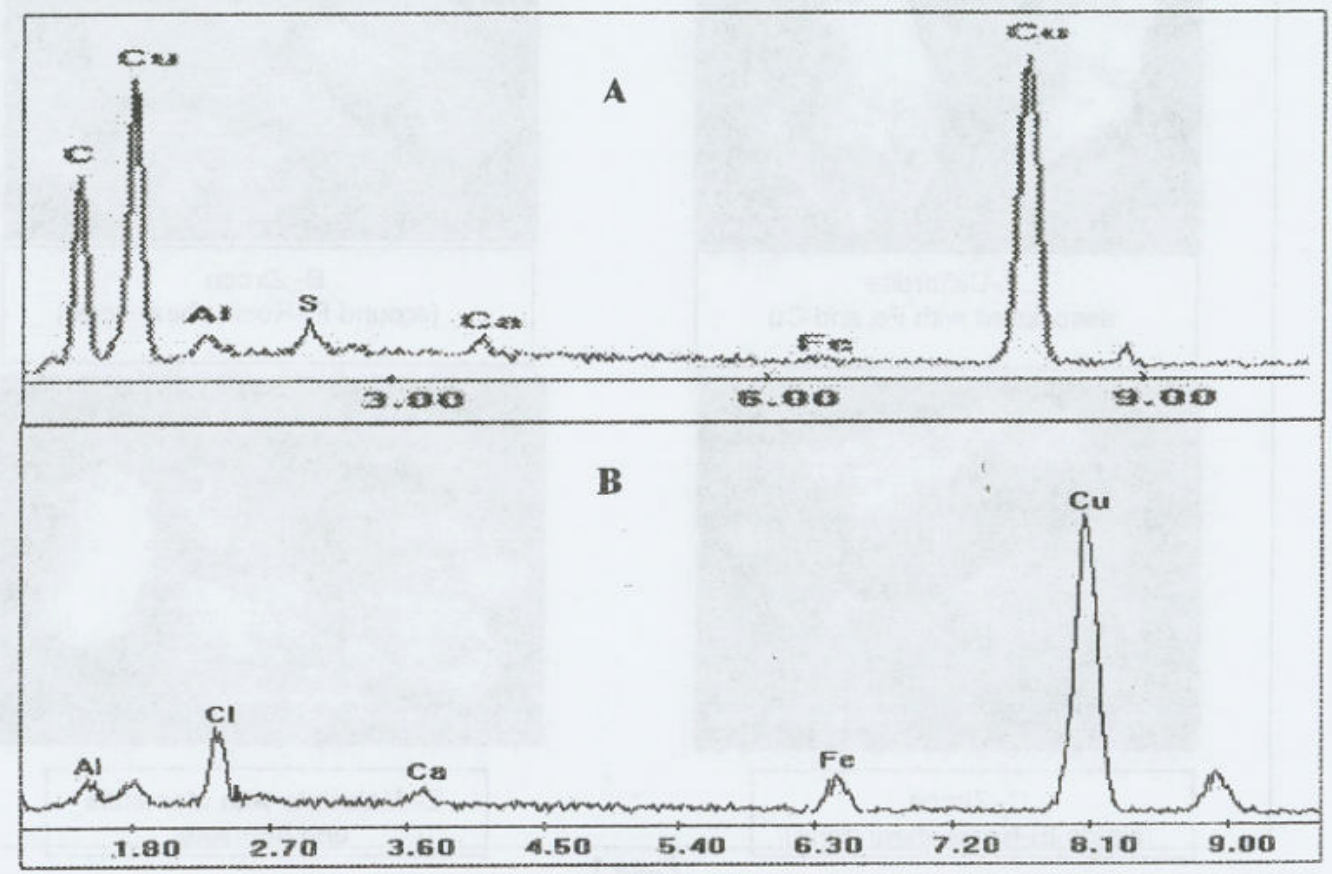

Fig. 6. ESEM analyses showing the charts of the analysed grains of A- malachite $\mathrm{Cu} 2 \mathrm{CO} 3(\mathrm{OH}) 2$, B- atacamite $\mathrm{Cu} 2 \mathrm{Cl}(\mathrm{OH}) 3$.

About 168 total gamma-ray spectrometry measurements are collected and statistically analysed (Table 1). Some statistically parameters including mean, standard deviation and median of $\mathrm{K} \%, \mathrm{eU}$ and $\mathrm{eTh}$ concentrations have been calculated and interpreted (Table 1). Anomalous zones and spots are defined and chosen for detailed studies as follow.

\section{Total (Tc) radioactivity of El-Rosis shear zone}

Three main anomalies are observed on the total count radioactivity contour map of El-Rosis shear zone (Fig. 7). Table (1) shows that the gamma-ray spectrometry measurements along the shear zone are ranged between 15 and $104 \mathrm{Ur}$ with median equal to $33.4 \mathrm{Ur}$. Some higher radioactivity anomalies (more than $55 \mathrm{Ur}$ ) are recorded within the shear zone (Fig. 7). In this figure, the anomaly No. STC1 is related to the presence of $\mathrm{Cu}$-minerals associated with alteration product as ferrugination. The total count content in this anomaly reaches more than $94 \mathrm{Ur}$ 
and controlled by fractures and alteration of the area around it. The second anomaly STC2 is related to the Cu-minerals associated with the presence of argillic alteration (clay minerals). The third anomaly STc3 is related to the Cuminerals associated with alteration product as ferrugination, which exists along the fracture and cavities and as coating for spots along the shear zone. The total count content in this anomaly reaches more than $104 \mathrm{Ur}$ and controlled by fractures along the shear zone.

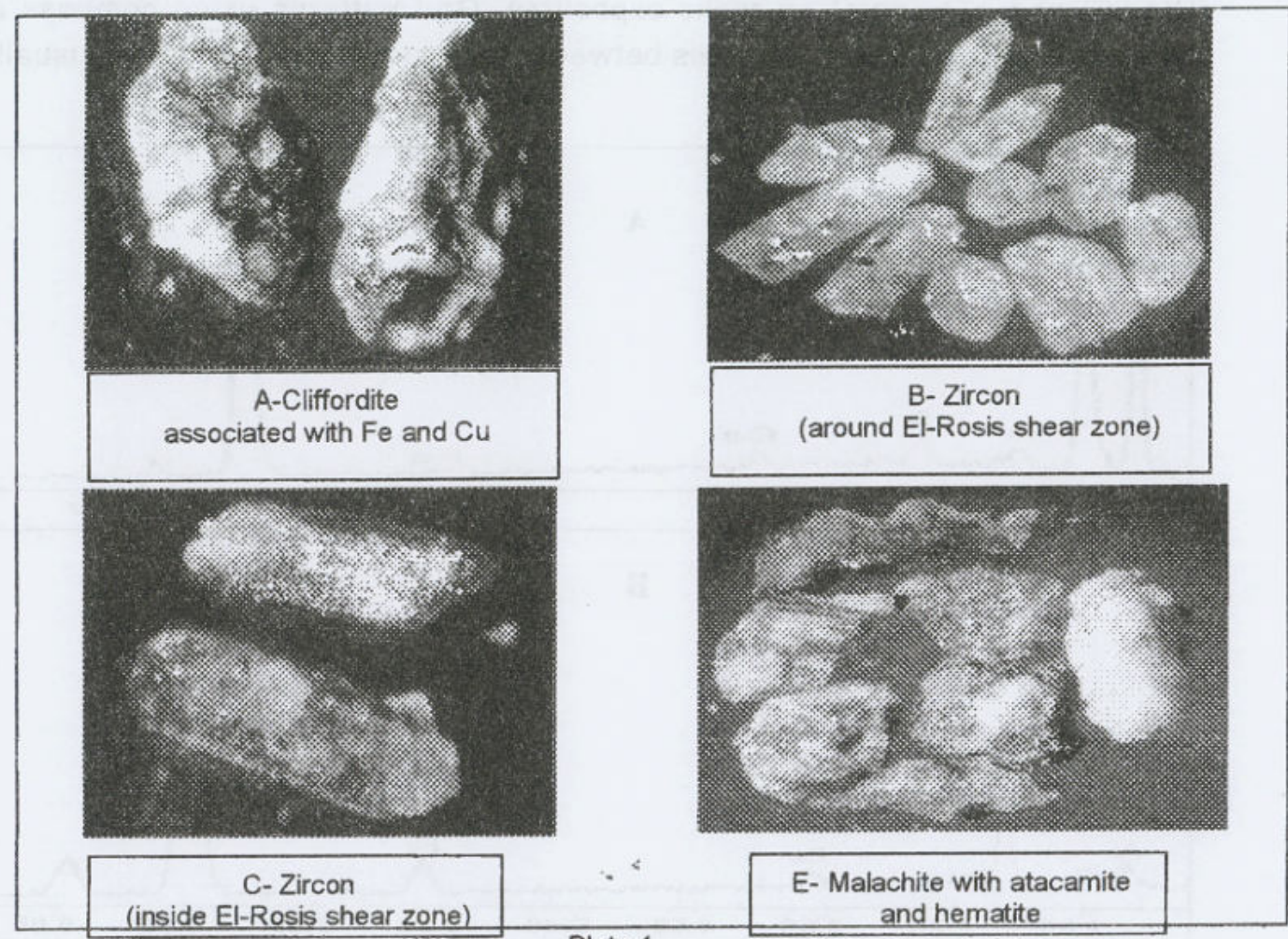

Plate 1

Table 1. Statistical analysis of ground $\gamma$-ray Spectrometric survey.

\begin{tabular}{lrrrrrr} 
& \multicolumn{1}{l}{ Ur } & \multicolumn{1}{c}{ K\% } & \multicolumn{1}{c}{ Uppm } & \multicolumn{1}{c}{ Th ppm } & \multicolumn{1}{l}{ U/Th } & \multicolumn{2}{c}{ Th/Eu } \\
\hline Minimum: & 15.1 & 0.7 & 0.3 & 2.03 & 0.01 & 0.12 \\
25\%-tile: & 30.3 & 4.6 & 3.3 & 19.4 & 0.14 & 3.61 \\
Median: & 33.4 & 5.2 & 4.4 & 22.9 & 0.20 & 5.09 \\
75\%-tile: & 38.5 & 6.0 & 6.0 & 25.4 & 0.28 & 7.24 \\
Maximum: & 104.6 & 13.4 & 65.7 & 51.0 & 8.01 & 99.67 \\
Midrange: & 59.85 & 7.05 & 33.0 & 26.52 & 4.01 & 49.90 \\
Range: & 89.5 & 12.7 & 65.4 & 48.97 & 8.00 & 99.54 \\
Mean: & 36.59 & 5.43 & 5.88 & 22.80 & 0.32 & 6.54 \\
Standard & 11.27 & 1.43 & 7.33 & 5.80 & 0.73 & 8.34 \\
Deviation: & & & & & & \\
\hline
\end{tabular}




\section{Potassium distribution map of El-Rosis shear zone}

Potassium contour map of El-Rosis shear zone (Fig. 8) and table (1) show that the rocks within shear zone have $\mathrm{K}$ contents between 0.7 and 13.4 of $\mathrm{K} \%$ with median $5.2 \%$. Some small anomalies of highly $\mathrm{K} \%$-concentrations present along line overlying the shear zone more than $8 \%$ of $\mathrm{K}$, and related by alteration spots along and around the shear zone.

\section{Uranium distribution map of El-Rosis shear zone}

The eU contour map (Fig. 9) shows that the uranium concentration of El-Rosis shear zone have two main anomalies enclosed between minimum $0.3 \mathrm{ppm}$ and maximum $65.7 \mathrm{ppm}$ with median $4.4 \mathrm{ppm}$ uranium. These uranium anomalies, which represented by the contour lines more than $20 \mathrm{ppm}$ are described as following:

The anomaly $\mathrm{No} . \mathrm{SU}_{1}$ (Fig. 9) is related to the presence of Cu-minerals and alteration products as ferrugination. It occurs along the fractures and cavities and shows green colour. It contains secondary uranium mineral (cliffordite UTe309), with characteristic yellow colour. The average eU content is more than $65 \mathrm{ppm}$. The second anomaly SU2 is also controlled by fractures and hematitization of the granite wall rocks, with the presence of argillic alteration. The eU content reaches $51 \mathrm{ppm}$ and extended about one meter and no uranium minerals were separated from this sample.

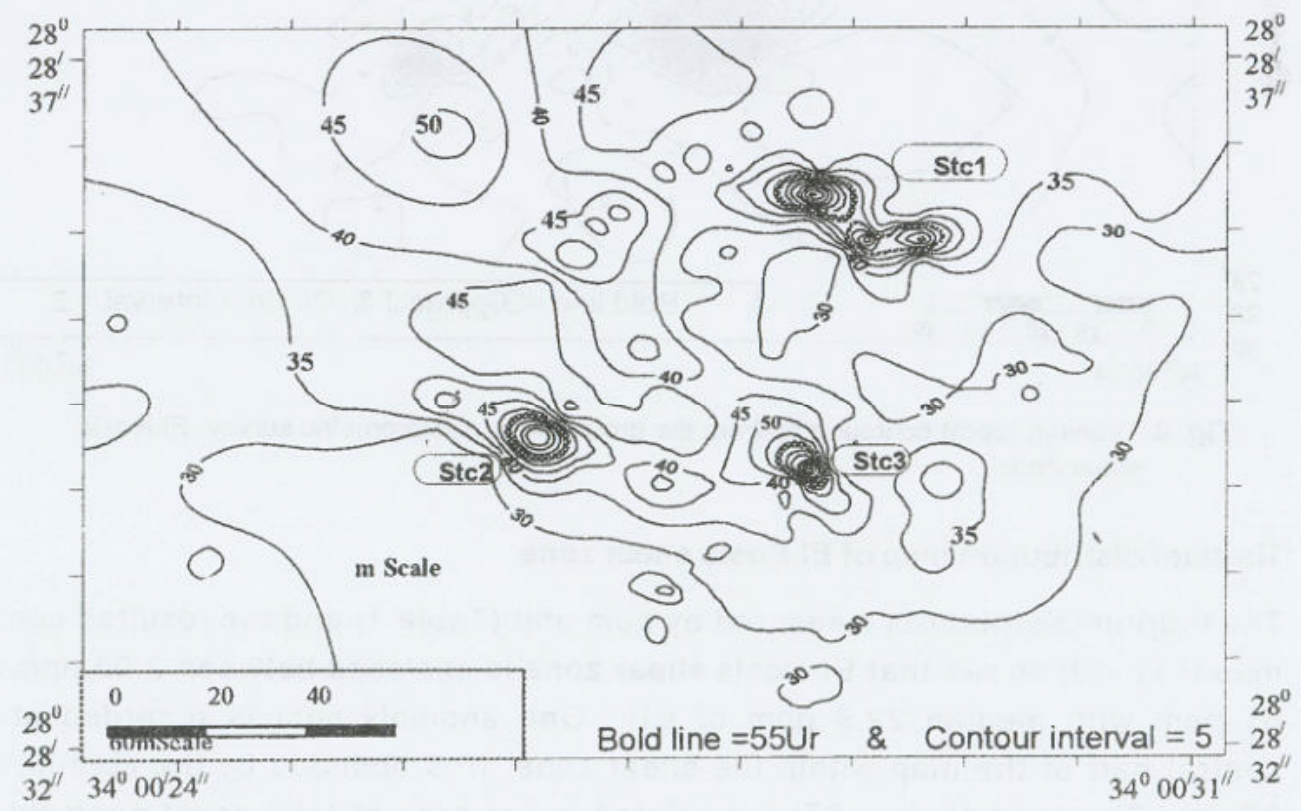

Fig. 7. Total count (Ur) contour map from ground $\gamma$-ray spectrometric survey, El-Rosis shear zone. 


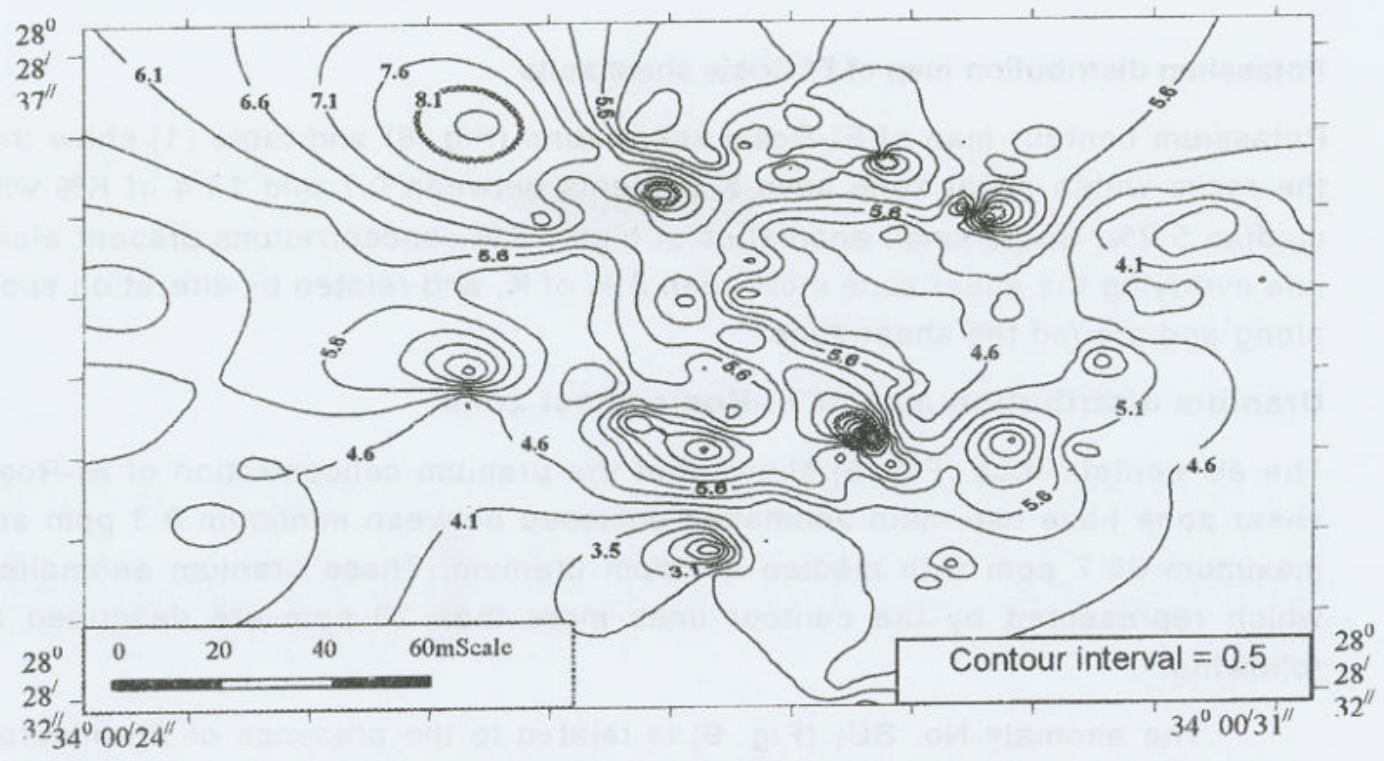

Fig. 8. Potassium (\%) contour map from the ground $\gamma$-ray spectrometric survey, El-Rosis shear zone.

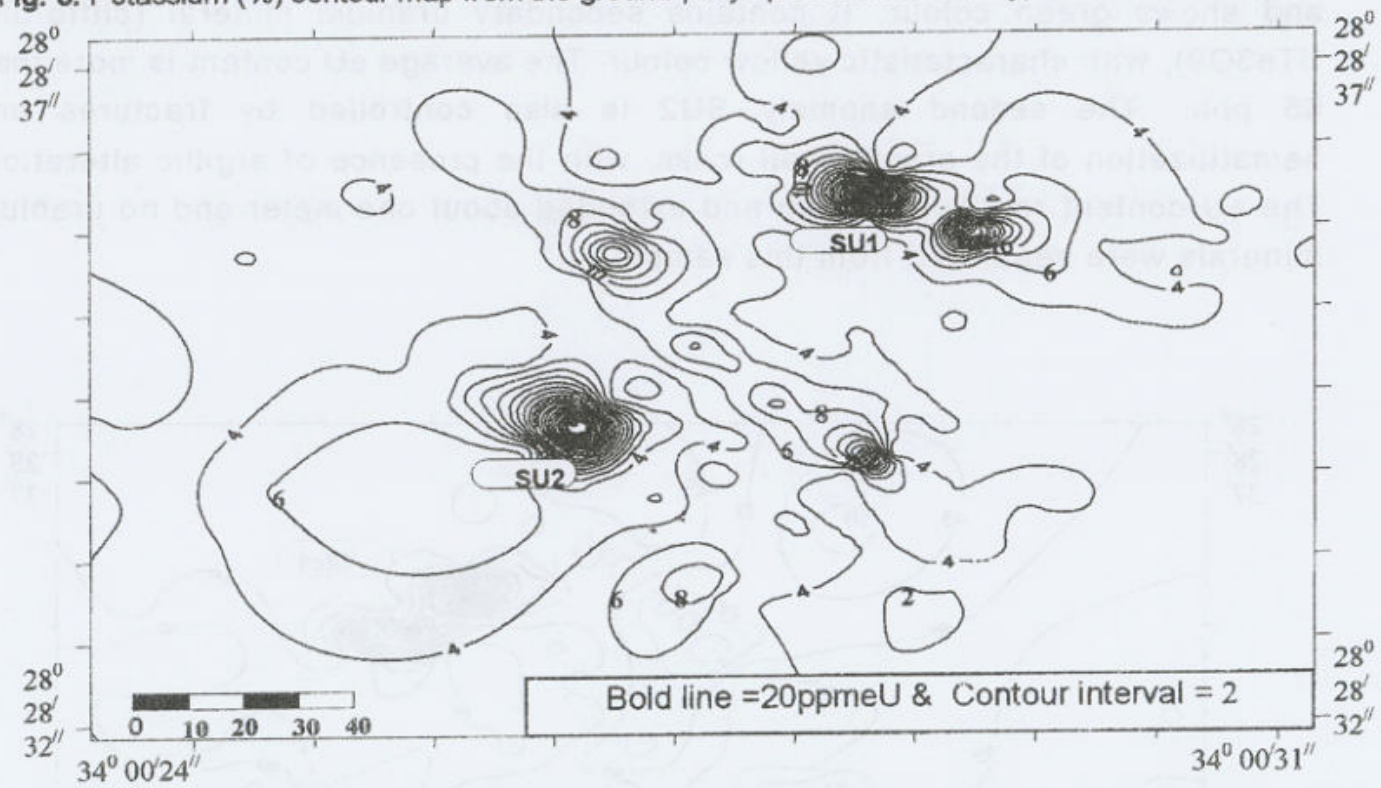

Fig. 9. Uranium (ppm) contour map from the ground $\gamma$-ray spectrometric survey, El-Rosis shear zone

\section{Thorium distribution map of El-Rosis shear zone}

The thorium distribution measured by ppm unit (Table 1) and the resulted contour map (Fig. 10) shows that El-Rosis shear zone is enclosed between $2.03 \mathrm{ppm}$ and $51 \mathrm{ppm}$ with median $22.9 \mathrm{ppm}$ of eTh. One anomaly spot is recorded at the central part of the map within the shear zone. It is bounded by the contour line $35 \mathrm{ppm}$. The anomaly No. STh1 is related to the area of total count anomaly No STC3 (Fig. 7) and the equivalent thorium in these spot (51 ppm) are responsible for the highest reading of total count (104.6 Ur). The uranium in these spot is relatively low (13.4 ppm). In this spots the thorium was fixed because thorium is 
relatively immobile according to uranium and the limited redistribution of uranium and thorium during the magma evolution and/or alteration processes, which make some uranium have been absorbed on altered mafic minerals and iron oxides.

\section{Relationship between eU/eTh and the presence of uranium mineralization}

The presence of one anomaly spot exceeding 1.5 of eU/eTh (Fig. 11) which mean according to Charbonneau and Ford (1977) an increase in equivalent uranium along with the increase in eU/eTh ratio may suggest a zone of uranium mineralization. Also by comparing the eU/eTh map with the geologic map and equivalent uranium contour map, can be noticed that the anomaly in Fig. 11 is related to the uranium anomaly $\mathrm{No} \mathrm{SU}_{1}$ in Fig. 9 which consider the best exposed for uranium mineralization. Cliffordite mineral was separated from that mineralized zone.

\section{Uranium-thorium variation}

The initial measurements of $U$ and Th contents of the granites and the shear zone on the other hand and the Th/U ratios values will allow to have an idea about the uranium favorability and concentrations in the mineralized shear zone within the granite rocks. As a matter of fact, uranium-rich granites have much more uranium content 3-4 times more than Clark abundance (4 ppm) of the granite in the world, i.e. more than $12-16 \mathrm{ppm}$.

The determination of uranium content will be an' essential factor in delineating the radioactivity of different shear zone areas, along the granite rocks. The most trouble is coming from the migration of uranium due to mobilization, so thorium and potassium measurements are very important due to their behavior during alterations and other processes because the lower mobility of thorium and stability of its content value relative to uranium.

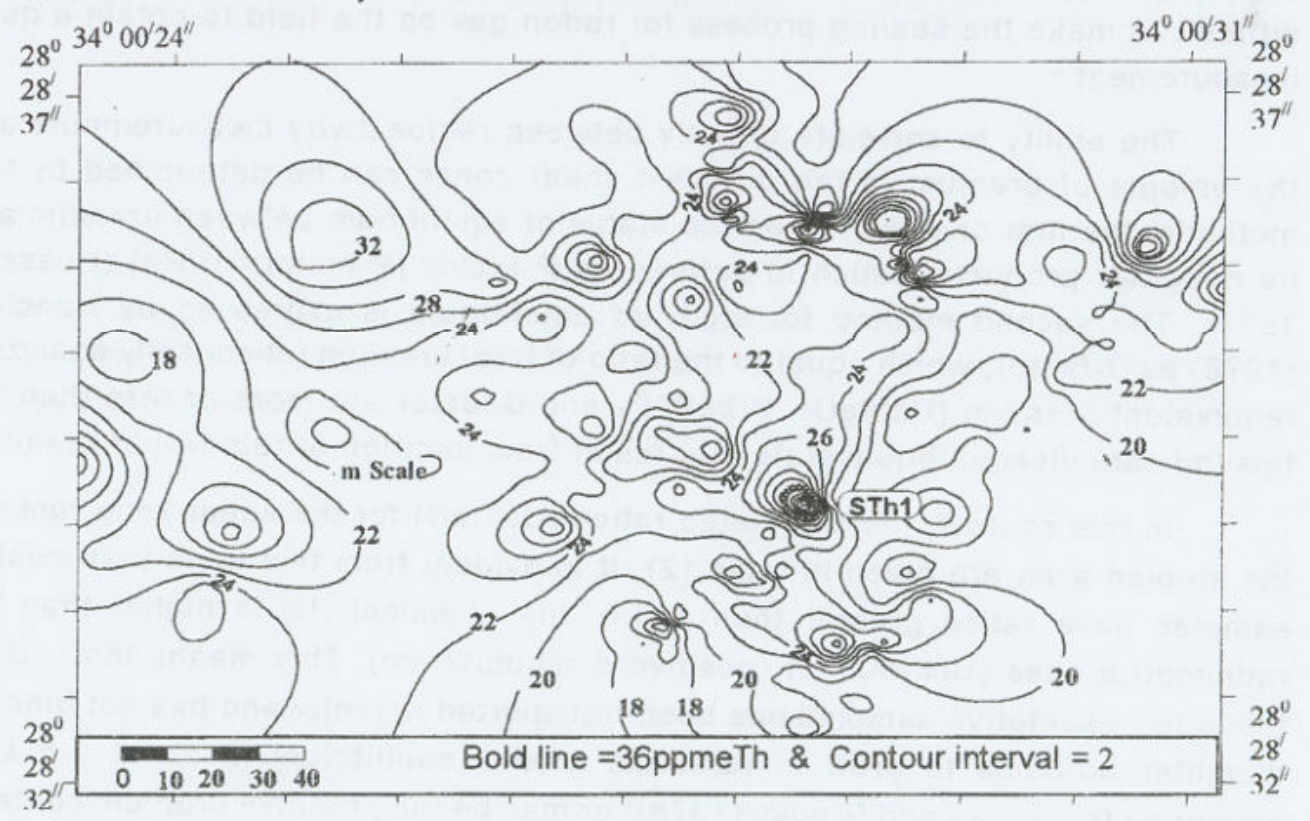

Fig. 10. Thorium (ppm) contour map from the ground $\gamma$-ray spectrometric survey, El-Rosis shear zone. 


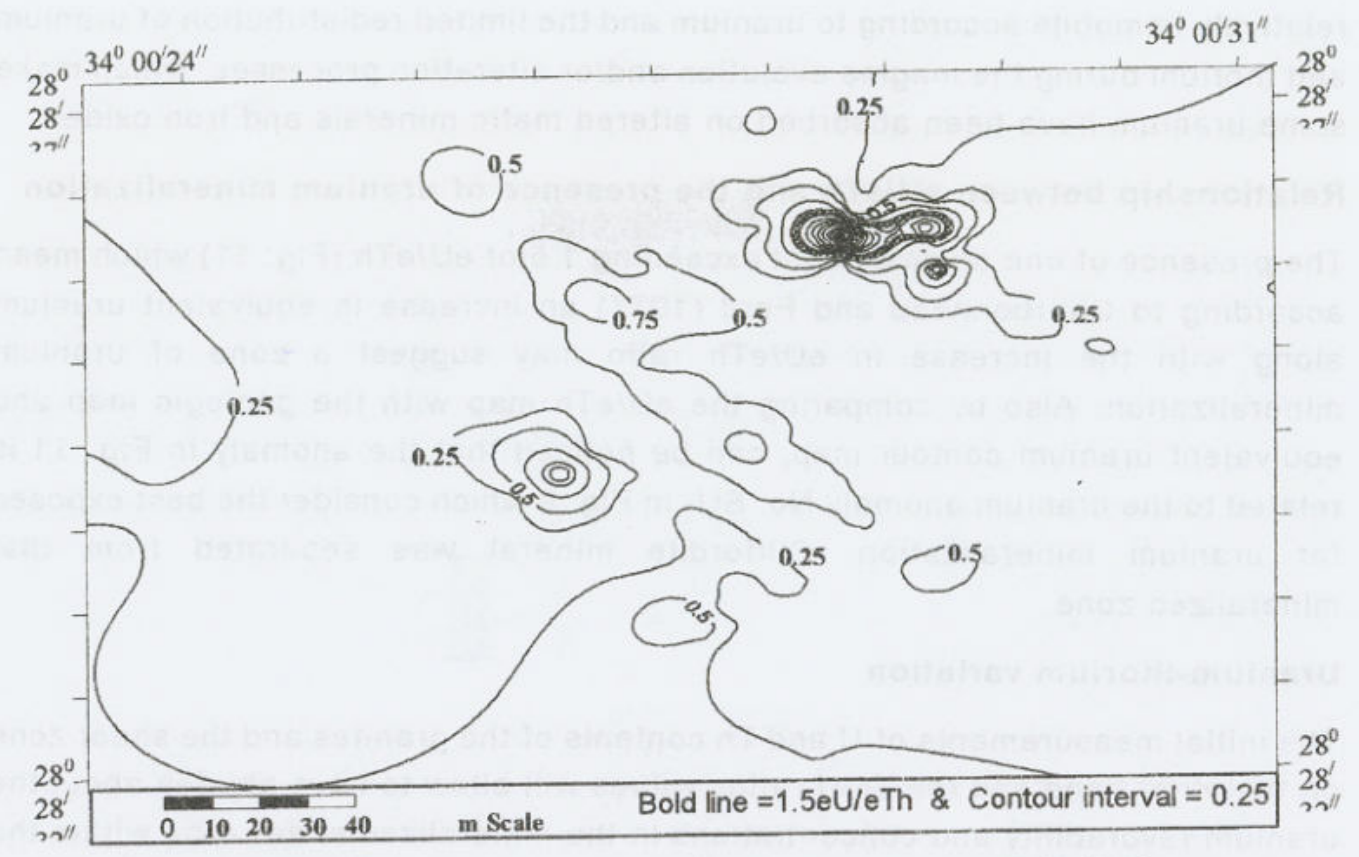

Fig. 11. Uranium / thorium ratio contour map of El-Rosis shear zone, El-Rosis shear zone.

The normal ratio of Th/U for the average granite rocks is around 3.8 , if the thorium anomalies are accompanied by Th/U ratios greater than 5 , uranium loss from the basement rock seems probably. Conversely, if the ratio is less than 3 , uranium was probably not lost (Stuckless, 1979).

The Th/U ratios are in its general case, shows fluctuating values in the $\mathrm{Th} / \mathrm{U}$ and $\mathrm{Uch} / \mathrm{eU}$ ratios may be due to loss of radon gas according to the solubility of radon in water and its leakage through vugs and pore spaces as well as along faults and shear zone fissures and planes. On the other hand, it is difficult to make the sealing process for radon gas on the field to obtain a quite measurement.

The ability to correlate directly between radioactivity measurements and the amount of uranium in the different shear zones can be determined by two methods, the first one depend on the status of equilibrium between uranium and its daughter products, which is defined as P-factor [P-factor=U/Ra] (Hussein, 1978). The second method for study of equilibrium is expressed by Hansink, (1976) as D-factor, which equal to the ratio of total uranium (chemically analyzed) lequivalent uranium $(\mathrm{Uch} / \mathrm{eU})$ ). If both $\mathrm{P}$ - and $\mathrm{d}$-factor are more or less than 1.0 this indicate disequilibrium state that result from addition or removal of uranium.

In this context, the calculated ratios ( $U \mathrm{ch} / \mathrm{eU}$ ) for the shear zone rocks in the studied area are given in table (2). It is evident from this table that most of samples have ratios greater than 1 , i.e. the chemical $(U)$ is higher than the radiometric ones (Uch/eU $>1$; positive disequilibrium). This means that, $(U)$ in these representative samples has been transported recently and has not time for daughter products to grow in (uranium attains equilibrium in about $1.5 \mathrm{M}$.a. according to Reeves and Brooks (1978)) or may be the primitive uranium contents are redistributed by subsequent processes such as hydrothermal and/or meteoric solutions. 
So, it is clear from the above mentioned results that the +ve disequilibrium state dominates the shear zone of the studied areas, may be due to certain geological processes such as hydrothermal alterations resulting in the disturbance of the equilibrium state. Also groundwater may act on some uranium deposits and causes leaching of uranium from its original place and the secondary processes where the leachable uranium from the granite could be trapped or precipitated by the alteration products such as kaolinite and iron oxides.

According to Charbonneau (1982) an increase in eU/eTh ratio with eU indicates postmagmatic remobilization of uranium. A lack of variation indicates no such remobilization. An inverse correlation between eU/eTh and eTh indicates radioelement distributions that were least partly governed by magmatic processes.

The correlations between uranium and thorium concentrations within the shear zone of the El-Rosis area are illustrated in Fig. 12. The uranium/thorium ratio has positive corelation with uranium concentration and weak inversely with thorium concentrations. So, the interpretation of these trends indicates that radioelements distributions were least partly governed by post magmatic redistribution of uranium and week redistribution of uranium during alteration processes.

A

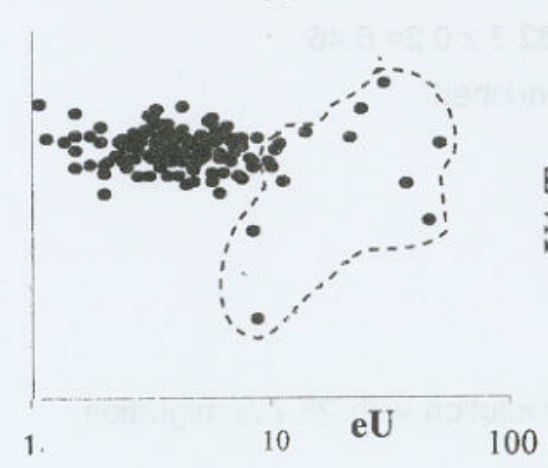

B

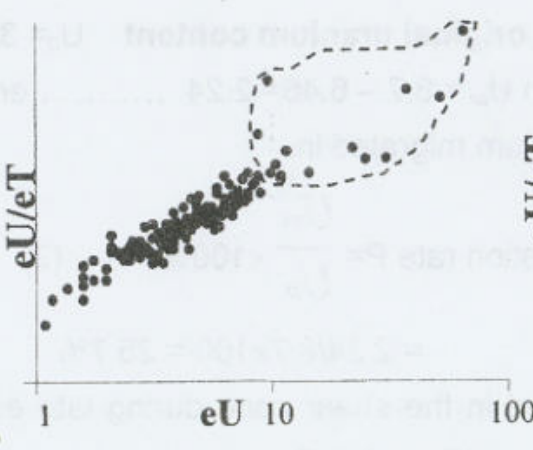

C

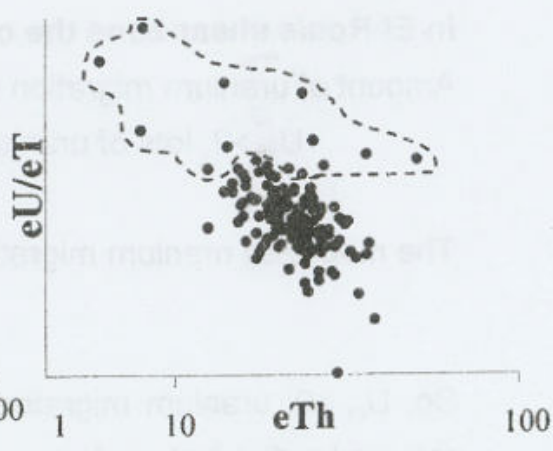

Figure 12. Plot of (A)-eU versus eTh, (B)-eU/eTh versus uranium and (C)- eU/eTh ratio versus thorium. Dashed lines bounded the anomalies samples.

This can be achieved through the calculations of the migration out or

in of uranium. Calculation procedures (NMA, 1999) will be summarized in the following steps.

A- Calculate paleo-uranium background (i.e. original uranium content $U_{0}$ ), which means to multiply the average Th content detected from ground $\gamma$-ray spectrometric survey by average regional U/Th ratio. $\mathrm{U}_{0}=\overline{e T h} \cdot \frac{\bar{U}}{T h}$

where: $\overline{e T h}=$ the average Th content. $\quad \frac{\bar{U}}{T h}=$ the average regional U/Th ratio.

B- Calculate amount of mobilized uranium (i.e. amount of uranium migration $U_{m}$ ) through the following equation:

$$
U_{m}=U_{p}-U_{0}
$$


Where: $U_{p}$ means average uranium content

If $U_{m}>0$, uranium migrated in the geologic body during late evolution.

$U_{m}<0$, uranium lost in the geologic body during late evolution,

$U_{m}>2$, lots of uranium migrated in. $U_{m}<-2$, lots of uranium migrated out.

$-2<U_{m}<2$, migration equivalent in and out

C. Calculate the mobilized uranium migration rate $\mathrm{P}=\frac{U_{m}}{U_{p}} \times 100 \%$

A. Calculate paleo-uranium background for hosted granite rocks

$$
\mathrm{U}_{0}=\overline{e T h} \cdot \frac{\bar{U}}{T h} \cdots \cdots \cdots . . .(1) \quad \mathrm{U}_{0}=22.8 \times 0.2=4.56
$$

B. Calculate amount of uranium migration $\mathrm{U}_{\mathrm{m}}=\mathrm{U}_{\mathrm{p}}-\mathrm{U}_{0}$

$U_{m}=4.5-4.56=-0.06$ depleted

$-2<U_{m}<2$, migration equivalent in and out

The mobilized uranium migration rate $\mathrm{P}=\frac{U_{m}}{U_{p}} \times 100 \%$

$$
=0.06 / 4.5 \times 100=1.33 \%
$$

So, $U_{m}<0$, this indicates that $1.33 \%$ of the uranium content of hosted granite was migrated out.

In El-Rosis shear zone the original uranium content $U_{0}=32.3 \times 0.2=6.46$

Amount of uranium migration $U_{m}=8.7-6.46=2.24$ enriched

$U_{m}>2$, lots of uranium migrated in.

The mobilized uranium migration rate $\mathrm{P}=\frac{U_{m}}{U_{p}} \times 100 \%$

$$
=2.24 / 8.7 \times 100=25.7 \%
$$

So, $U_{m}>0$, uranium migrated in the shear zone during late evolution with $25.7 \%$ migration rate and redistribution during or after alteration.

In El-Rosis shear zone anomalies the original uranium content

$$
\mathrm{U}_{0}=34.9 \times 0.2=6.98
$$

Amount of uranium migration $U_{m}=23.9-6.98=16.9$ enriched

$$
\mathrm{U}_{\mathrm{m}}>2 \text {, lots of uranium migrated in. }
$$

The mobilized uranium migration rate $\mathrm{P}=\frac{U_{m}}{U_{p}} \times 100 \%$

$$
P=16.9 / 23.9 \times 100=70.7 \%
$$

So, $U_{m}>0$, uranium migrated in the shear zone anomalies area during late evolution with $70.7 \%$ migration rate and redistribution during or after alteration. 
Table (2): Summarizes the radioactive parameters with depleted and enriched uranium

\begin{tabular}{|c|c|c|c|c|c|c|c|c|c|c|c|}
\hline Type & $\mathrm{eU}$ & eTh & $U_{c h}$ & $\frac{\stackrel{D}{c}}{3}$ & $\frac{\stackrel{\oplus}{7}}{\frac{\Phi}{c}}$ & $\frac{c}{\frac{\mathfrak{q}}{c}}$ & $U_{0}$ & $U_{p}$ & $\mathrm{U}_{\mathrm{m}}$ & $\mathrm{P} \%$ & remarks \\
\hline $\begin{array}{c}\text { Total granite } \\
\text { area }\end{array}$ & 4.5 & 22.8 & 8.4 & 0.2 & 5.05 & 1.87 & 4.56 & 4.5 & $\overline{0.06}$ & 1.33 & $\begin{array}{c}\text { Depleted } \\
\text { (migrated } \\
\text { out) }\end{array}$ \\
\hline $\begin{array}{c}\text { Total shear } \\
\text { zone }\end{array}$ & 8.7 & 32.3 & 70 & 0.3 & 3.71 & 8.05 & 6.46 & 8.7 & 2.24 & 25.7 & $\begin{array}{l}\text { Enriched } \\
\text { (migrated in) }\end{array}$ \\
\hline $\begin{array}{c}\text { Anomalies } \\
\text { spots }\end{array}$ & 23.9 & 34.9 & 143.2 & 2.9 & 1.46 & 5.99 & 6.98 & 23.9 & 16.9 & 70.7 & $\begin{array}{c}\text { Enriched } \\
\text { (migrated in) }\end{array}$ \\
\hline
\end{tabular}

\section{Conclusions}

From the foregoing discussion, it could be concluded that enrichments of uranium in El-Rosis shear zone (uranium migrated in) may be carried by the surface and meteoric water from host granite rocks (uranium migrated out) and also during the course of the hydrothermal solutions migration from deeper source through the structural weaknesses of the shear zone.

Uraniferous solutions have penetrated along zones previously opened by mineralizing fluids which caused hematitization and argillic alterations. The hydrothermal fluids responsible for the presence of uranium minerals within the shear zone have been activated during the passage of these fluids through the fractures of the shear zone rocks. Elements such as $\mathrm{Si}, \mathrm{Fe}, \mathrm{K}, \mathrm{Ca}, \mathrm{Na}, \mathrm{U}, \mathrm{V}, \mathrm{Y}$, $\mathrm{Nb}, \mathrm{Ta}, \mathrm{Ti}, \mathrm{P}$ and some REEs were mobilised, and therefore concentrated, then transported and redistributed and redeposited.

In El-Rosis shear zone, it can be concluded that the gained uranium in the shear zone ( $U$ migrated in) is too much more than uranium lost from host granite rock (migrated out) and the presence of Te element in cliffordite indicate that, the hydrothermal solution is the source of uranium mineral precipitated in El-Rosis shear zone.

\section{References}

Barron, T., (1907): The topography and geology of western Sinai, Egypt. Surv. Dept., Cairo, $241 \mathrm{p}$.

Bentor, Y. K., (1985): The crustal evolution of the Arabo-Nubian Massif with special reference to the Sinai Peninsula, Precambrian Res., 28, 1-74.

Charbonneau, B. W., (1982): Radiometric study of three radioactive granites in the Canadian Sheild: Elliot Lake, Ontario; Fort Smith, and Fury and Hecia, N.W.T.; in uranium in Granites, Geol. Surv. of Can., 91-99.

Charbonneau, B.W. and Ford, K.L., (1977): Uranium mineralization at the base of the Windsor Group, South Maitland, Nova Scotia; Current research, Part A, Geol. Surv. Can., Paper 78-1A, p. 419-425.

Claus, (1936): in Poldervaart, A., (1956): Zircons in rocks II. Igneous rocks. Am. J. Sci., V. 254: pp. 521-554.

Ei-Ghawaby, M. A., (1984): Image linear analytical approach to copper mineral exploration in South Sinai, Egypt. International Atomic Energy Agency, United Nation Educational Scientific and Cultural Organization.

El-Ghawaby, M. A., Hegazi, A. M., Khalifa, I. H. and Arnous, M. O., (2000): Tectonic and mineralization style of Saint Catherine Environs, south Sinai, Egypt. M.E.R.C. Ain Shams Univ., Earth Sci. Se. v. 14: p. 40-55. 
El-Shazly, E. M., Abdel-Hady, M. A., El-Ghawaby, M. A., El-Kassas, I. A. \& El-Shazly, M. M., (1974): Geology of Sinai Peninsula from ERTS Satellite images. Remote Sensing Research Projects, Academy of Scientific Research and Technology, Cairo, Egypt.

El-Sheshtawy, Y. A., (1984): Petrographical and geochemical studies of granitic rocks around Wadi El-Sheikh, southwest Sinai, Egypt. Ph. D. Thesis, Al-Azhar Univ., Cairo, Egypt. $213 \mathrm{p}$.

Eyal, M., (1975): Stages in the magmatic history of the Precambrian in Sinai and Southern Negev. Thesis, Hebrew Univ., Unpublished Ph. D. Thesis.

Eyal, M., and Hezkiyahu, T., (1980): Katherine pluton. The outlines of petrological framework Isr. Jour. Earth Sci; V. 29, pp. 24-52.

Frondel, C., (1958): Systematic mineralogy of uranium and thorium, U. S. Geol. Surv. Bull $1064,400 p$.

Gaines, R. V., (1969): Cliffordite - a new tellurite mineral from Moctezuma, Sonora, Mexico. Amer. Mineral., V. 54, pp. 697-701.

Hansink, J. K., (1976): Equilibrium analysis of sandstone rollfront uranium deposits. Proceeding Inter. Symposium on exploration of uranium deposits Int. Atomic Energy Agency, Vienna, 638-693.

Hussein, H. A., (1978): Lecture course in nuclear geology. Nuclear Materials Authority of Egypt, 101p.

Ibrahim, M. E., (1991): Geology and radioactivity of Wadi Zaghra area, South central Sinai, Egypt. Ph. D. Thesis, Mansoura Univ., Egypt, 181p.

Niazy, E. A., Shalaby, I. M. and Abdel Rahim, S. H., (1995): Wall rock alteration associated with the copper mineralization of Wadi El-Regita, Southern Sinai. Egypt Annals, Geol. Surv. Egypt, V. XX. pp. 433-450

Nuclear Materials Authority, (1999): Uranium evaluation in Abu Zeneima Area, Sinai, Egypt. Report, (Egyptian-Chinese Experts). May, 1999. 259p.

Reeves, R. D. and Brooks, R. R., (1978): Trace element analyses of geological materials. John Wiley \& Sons Inc., New York, 421p.

Shimron, A. E., (1980): Proterozoic island arc volcanism and sedimentation in Sinai Precam. Res., $12,437-458$.

Stuckless J. S., (1979): Uranium and thorium concentrations in precambrian granites as indicators of a uranium province in central Wyoming. Contrib. Geology. Univ., Wyo., 17 , no. 2 1979, 173-8.

Wyatt, M., (1954): Zircon as provenance indicators. Am. Min., V. 39, No. 11-12, pp. 983-990.

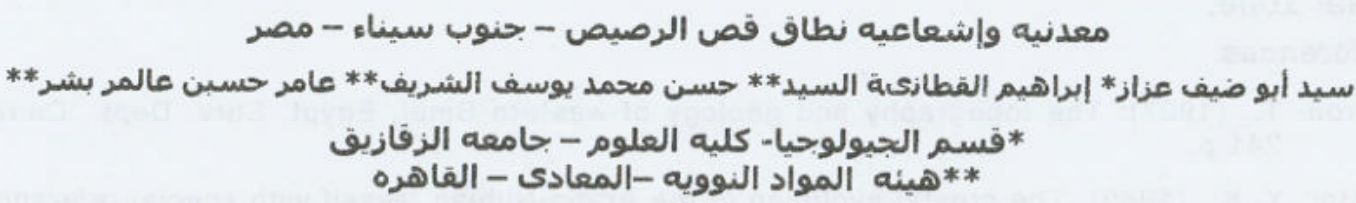

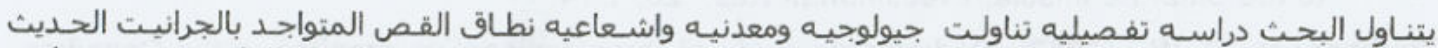

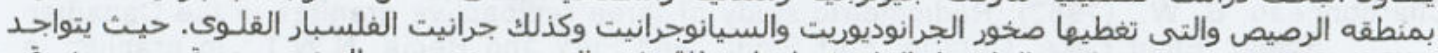

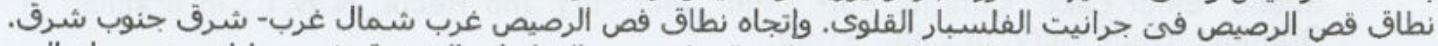

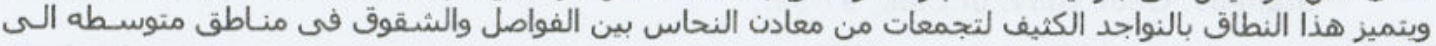

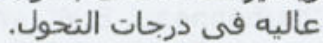

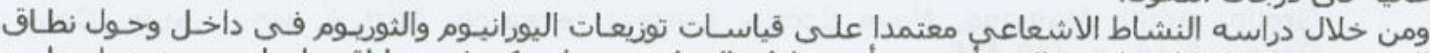

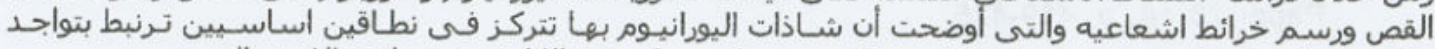

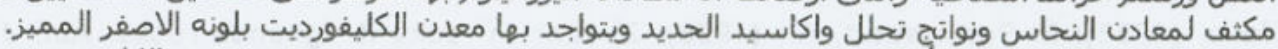

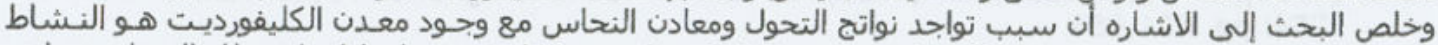

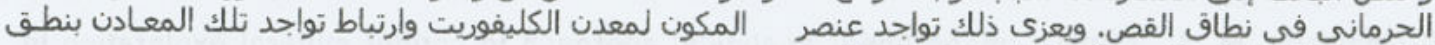
التكسير والفواصل والشقوق نطاق داخل نطاق قص الرصيص. 